\title{
Determinants of stock price volatility: Evidence from cement industry
}

\author{
Arshad Mehmood ${ }^{a^{*}}$, Muhammad Hafeez Ullah ${ }^{\mathrm{b}}$ and Najam Ul sabeeh ${ }^{\mathrm{c}}$
}

${ }^{a}$ University of Sargodha, Sargodha, Pakistan

${ }^{b}$ Riphah international university, Islamabad, Pakistan

'International Islamic Universitty Islamabad, Pakistan

\begin{tabular}{l}
\hline C H R O N I C L E \\
\hline Article history: \\
Received November 11, 2018 \\
Received in revised format \\
February 122019 \\
Accepted February 222019 \\
Available online \\
February 22 2019 \\
\hline Keywords: \\
Stock price volatility \\
Dividend payout ratio \\
Pakistan Stock Exchange \\
PSX
\end{tabular}

\author{
A B S T R A C T
}

\begin{abstract}
This paper presents a survey on the effect of corporate dividend payout policy on stock price volatility. The primary objective of this study is to examine the impact of dividend payout ratio on the stock price volatility in Pakistan Stock Exchange. A sample of 15 firms from PSX is considered and the study covers the historical data over the period 2011-2015. Stock Price volatility is the dependent variable in this study and dividend payout ratio is the main independent variable. For this purpose, some other independent variables are also included such as Earnings Volatility, Size of the firm, Leverage and Assets Growth. The study has determined a positive relationship between stock price volatility and dividend payout ratio. In addition, our results show that earnings volatility and leverage had negative relationship with stock price volatility. Other independent variables including assets growth and size have maintained positive relationship with stock price volatility.
\end{abstract}

\section{Introduction}

Stock price volatility (PV) has always been a concern among researchers for stock price prediction (Nishat \& Irfan, 2004; Zakaria et al., 2012; Suliman et al., 2013). It is a universal fact in the stock market and PV results unexpected changes in the stock prices. Dividend is part of the earnings which must be distributed among shareholders. The main purpose of financial management is to maximize the wealth of firm's owners. Dividends are more than just tool to distribute the surplus profit of the firms. Any significant difference in the rate of distributions may also influence on share prices. Dividend decision at corporate level includes dividend yield (DY), return on equity (ROE) dividend payout ratio (DPR), dividend per share ratio (DPS) \& earnings volatility (EV). There are three types of dividend payout in a financial year; namely quarterly, semiannually and annually. There are several studies to analyze the relationship between stock price volatility and dividends structure. The researchers have originated both positive and negative relationship between dividend and PV. There are many theories about the share price volatility and dividends like Irrelevance of dividend theory, Signaling effect theory and relevance theory but this study helps to recognize the behavior of dividend policy in relationship with the changes in stock prices. Pakistan Stock Exchange (PSX) is the official places where hundreds of the different Pakistani companies are actively offering the shares of their 
firms. Pakistani firms are often family-owned and liable to pay no attention to foreigners or minority interests linked with payouts, which ultimately leads to a conflict. This factor influences the firm's dividend-smoothing behavior on the financial market and makes it high-return, high-risk and investors need to consider a high risk. Share price volatility is the systematic risk faced by the investors.

\section{Literature review}

In first time, Miller and Modigliani (1959) worked on this topic. According to M\&M, firm's stock value is not relevant with dividend policy. They also concluded that firm's price influenced only by firms' earnings abilities. Black and Scholes (1974) also supported the theory of M\&M that there is no relevancy between share prices and dividend payouts. Pucket and Friend (1964) tries to find the relationship between dividend policy and stock price. They worked on controlling variables that have the ability to influence a firms' stock value and reported a positive relationship between several variables. Miller and Modigliani (1961) expanded their work and stated that dividend policy is relevant in an inefficient market where information is not symmetrically distributed.

Rock and Miller (1985) informed that irrelevancy may be occur only when all shareholders receives confirmed information related to the financial position of the company but in real practices board of directors show only favorable information and negative factors are not presented. According to Pradhan (2003) dividend policy influences the share price of firm. There is a positive relationship by three ways. First, when organizations announce to an increase in dividends then stock prices increase. Second, when organizations announce to decrease the dividends then stock prices decrease. Third, when the dividends remain constant, the firms' value also not vary.

Walter (1956) and Gordon (1963) presented the theory of "Bird in Hand" in which they believed that low risk stockholders mostly prefer short term benefits (dividends) over long term benefits (capital gain). Baskin (1989) conducted the theory in which they concentrated on the Manager's point of view that there is an optimum level of dividend ratio and firms are affecting because of dividend payouts. Holder et al. (1998) showed the same results that because of agency cost dividend policy relates to the means an agent or middleman, acting in the market who charges the commission. The managers and companies often prefer to save the agency cost and they preferred high dividends to stockholders.

Azhagaiah and Priya (2008) investigated the impact of dividend policy on share price volatility. Multiple regression tools showed that there was a considerable influence of dividend policy on the value of firm's stock in organic chemical firms but inorganic chemical firm's value of stock was not affected by dividend payout. Nazir et al. (2010) checked out the relationship between the stock price volatility and the dividend policy. The results show that dividend payout and dividend yield both had meaningful impact on share stock prices. Hussainey et al. (2010) examined the relationship between share price changes and dividend yield (DY) and payout ratio (POR) using the regression method and found a negative association.

Iqbal et al. (2014) conducted a survey to find the impact of dividend on stockholders wealth. They concluded that shareholders' wealth was highly influenced by dividend policy and both had positive relationship. Profilet and Bacon (2013) conducted a test to check the hypothesis by using regression that stock price volatility and dividends had negative correlation compared with other variables. The results concluded that those stocks are less risky with large dividend payouts and negative correlation between size stock price volatility. Ilaboya and Aggreh (2013) worked on the relationship between share price volatility and dividend policy. The finding of the work shows that dividend payout had insignificant impact on share price variability.

Bawa and Kaur (2013) examined the impact of dividend policy on firm's value. The results explored that shareholder's wealth by dividend paying organizations was increased more compared with nondividend paying organizations. Nazir et al. (2010) worked on how much effects accrued on stock prices 
by factors of volatility in the financial sector of Pakistan. Correlation and regression methods applied on panel data. There was a negative relationship detected between dividends and stock price volatility. Masum (2014) determined the relationship between dividend policy and share price volatility. While dividend yield and share price retained earnings ratio negatively influenced but statically showed insignificant relationship with stock market prices. Ansar et al. (2015) investigated the relationship between stockholder's wealth and dividend policy. Their work suggested after analysis the regression method that shareholders wealth and dividend policy contains a positive relationship and concluded that irrelevancy theories cannot be applied in underdeveloped countries like Pakistan. Khan (2014) inspected the association of dividend on share price of the organizations and concluded that dividends had no effect on stock prices. Zakaria et al. (2012) investigated the effect of dividend policy and reported that dividend policy was an important indicator for making decision in organizations.

\section{The proposed study}

\subsection{Theoretically framework}

Fig. 1 demonstrates the structure of the proposed study.

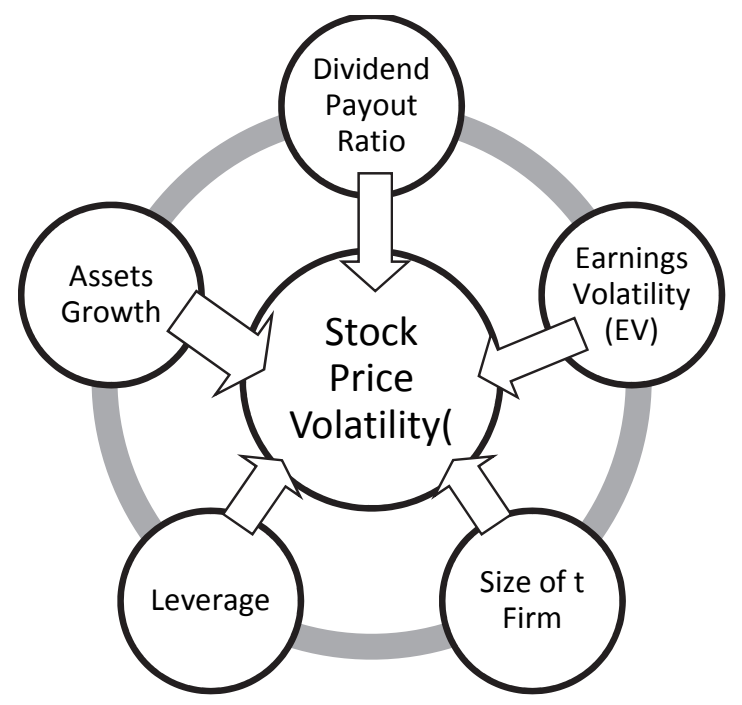

Fig. 1. The structure of the proposed study

\subsection{Study variables}

Stock Price Volatility is commonly associated with earning's volatility (EV), assets growth, size, long term debt ratio and dividend policy. Market risk is a further feature that can manipulate the dividend policy of the companies, because of this factor we have taken price volatility as dependent variable and dividend payout ratio, assets growth, earnings volatility and leverage as independent variables to check out different hypotheses. Here, may be result of this study have direct relationship between firm leverage and stock price volatility because of operating risk. Investors have low information about the value of stock in the market and more illiquid.

\subsection{Variables measurement}

\section{Price Volatility $(P V)$}

Stock price volatility (PV) is the dependent variable. Stock prices are taken from the historical data of Pakistan stock exchange. We calculate Stock Price volatility (PV) by taking yearly difference (difference between the maximum and minimum stock price in the stock market) of each stock firm, dividing it by the averages prices and then taking the square of that value. There is another measure of 
stock price volatility where we consider the high value and low value or by calculating the square of the standard deviation of the stock prices.

$$
P V=\left(\frac{\text { High Price - Low Price }}{\text { Average Price }}\right)^{2}
$$

\subsection{Dividend Payout Ratio (POR)}

Dividend payout ratio is measured by dividing the Total Dividend to Total Profit or total revenue or total earnings. We take total dividend and total earnings values from each year annual reports of every company.

$$
P O R=\frac{\text { Total Dividend }}{\text { Total Profit }}
$$

\subsection{Leverage (LEV)}

It is the ratio of firm's long term debt (excluding short term debt) to total assets.

$$
L E V=\frac{\text { Long Term Debt }}{\text { Total Assets }}
$$

\subsection{Assets Growth (ASG)}

Assets growth ratio is calculated by subtracting from the current year's total assets from the previous year's total assets divided on the current year's total assets.

$$
A S G=\frac{\text { Current Year's Total Assets }- \text { Previous Year's Total Asset }}{\text { Current Year's Total Assets }}
$$

\subsection{Earnings Volatility (EV)}

Earnings volatility is measured by standard deviation of the operating income before interest and taxes (EBIT) to total assets.

$$
E V=\text { Standard deviation of } \frac{\text { EBIT }}{\text { Current Year's Total Assets }}
$$

\subsection{Size}

This variable is calculated by taking the natural log of total assets of each year.

$$
S Z=\text { Natural log of (Total Assets) }
$$

\subsection{Description of Data and Sample}

We collect the data from the selected firms, which are listed in Pakistan Stock Exchange (PSX) and by considering the following conditions:

- Firms must be listed in PSX since 2010.

$\circ$ Firms should be part of cement sector.

- Firms have stable accounting period or cycle.

- During the research duration, there was no interruption on trading the shares.

$\circ$ There is a need for accessibility of data. 
We have followed the above conditions to collect the data of 15 companies from cement sector of Pakistan Stock Exchange from 2011 to 2015 as the samples for this study. We have collected the data from the historical data of Pakistan Stock Exchange (PSX) which were available. Next, the process of the collection we used was correlation and statistic report of this data and then we used the panel regression test for this study and the whole process was executed using the Eviews software.

\subsection{Hypothesis of the Study}

Hypotheses mean variables have different relationships with each other. The combine relationship between the variables is defined on the basis of available data and literature. We have used different statistical tools to clarify the relationships. There is no conformity of the results from statistical tools. We are concluding hypothesis according to literature and available information. There are following:

$\mathrm{H}_{1}$ : Dividend payout ratio has positive significant impact on the Stock price volatility.

\section{Model of the Study}

According to test of hypothesis the price volatility must be affected from dividend payout ratio. After all literature we have constructed the following,

$$
P V=\alpha+\beta_{1} P O R+\beta_{2} E V+\beta_{3} L E V+\beta_{4} A G+\beta_{5} S Z+\varepsilon
$$

Here, we have used panel regression in this study and the study shows the comprehensible relationship of stock price volatility (pv) with dividend payout ratio. Previous researchers reported that all variables that selected in this study had impact on dividend payout ratio and price volatility. The size of the firm, earnings volatility of the firm and the leverage of the firm had significant impact on stock price volatility.

\section{Discussion of analysis and Results}

Table: 1

Descriptive Statistics

\begin{tabular}{lcccccc}
\hline & Min & Max & Mean & Standard & Median & Standard \\
\hline Stock price & 0.0308 & 9.4838 & 0.5126 & 0.1286 & 0.2480 & 1.1137 \\
Earning volatility & 10.2771 & 31.6576 & 11.9042 & 0.6115 & 10.5308 & 5.2954 \\
POR & 0.0000 & 1.5497 & 0.4766 & 0.0429 & 0.3666 & 0.3712 \\
Leverage & 0.0005 & 0.5098 & 0.1399 & 0.0159 & 0.0947 & 0.1375 \\
Size & 11.7436 & 24.4020 & 18.4235 & 0.3488 & 17.5342 & 3.0204 \\
Assets Growth & -7.3139 & 0.9625 & -0.0960 & 0.1347 & 0.1029 & 1.1664 \\
\hline
\end{tabular}

Table 1 demonstrates some basic statistics associated with data used to examine the hypothesis of the survey.

Table 2

Correlation

\begin{tabular}{|c|c|c|c|c|c|c|}
\hline & PV & ASG & EV & POR & LEV & SZ \\
\hline PV & 1 & & & & & \\
\hline ASG & 0.0522 & 1 & & & & \\
\hline EV & -0.0508 & 0.058 & 1 & & & \\
\hline POR & 0.1335 & -0.014 & -0.106 & 1 & & \\
\hline LEV & -0.1502 & -0.131 & -0.039 & -0.0835 & 1 & \\
\hline SZ & 0.0550 & -0.083 & 0.126 & 0.0610 & 0.106 & 1 \\
\hline
\end{tabular}


Table 2 represents the correlation of all dependent variable and independent variables. It shows the relation of Assets Growth (ASG) with Stock price volatility as a positive value of 0.0522 . Earning Volatility (EV) maintains negative correlation of -0.0708 with PV. Dividend payout ratio (DPO) and stock price volatility (PV) also provided some positive but insignificant association.

Table 3

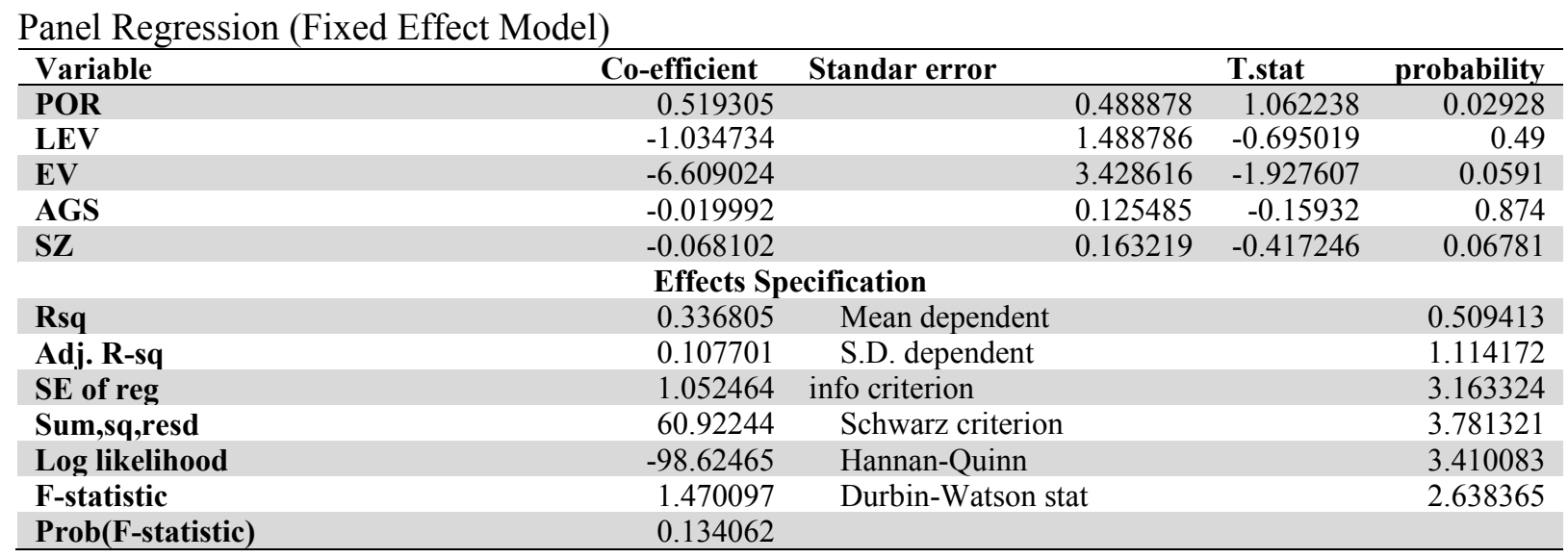

Table 4

Fixed effect Hausman test

\begin{tabular}{rccc}
\hline Effects Test & Statistic & d.f. & Prob. \\
\hline Cross-section F & 1.679932 & $(14.55)$ & 0.0871 \\
Cross-section Chi-square & 26.7006 & 14 & 0.0211 \\
\hline
\end{tabular}

The proposed study uses Eviews software package to examine the hypothesis of the survey. We first apply the Hausman test to choose between the fixed and the random effect and the results have indicated that only fixed effect model can be used. In Table 4, we represent the result of the fixed effect panel regression model, where the probability is significant and it means that we need to use fixed effect panel regression for the proposed model. We took dividend payout ratio and dividend yield as autonomous factors by taking information from 2011 to 2015. Results are exhibited in Table 3 (settle effect model) and the fix effect show yields better outcomes between both dividend yield and payout ratio. We have evaluated the relapse alongside some control factors in meticulous earning volatility, size, and leverage and assets growth to find that either the relationships are end of the week by including these control factors or not. It can be effortlessly translated from the given qualities in the tables that consequences of the both the models are to some degree comparative as far as bearings of the relationship, nonetheless, differing as for the level of criticalness. Stock prices of KSE-100 ordered firms are more influenced emphatically from dividend yield of the stocks, size of the firm, varieties in the net earnings of firms though, dividend payout ratio, leverage and assets growth are adversely driving stock prices of the example firms. Utilization of something beyond obligations in business and more assets are not seen by the financial specialists as a positive indication of execution my result is match with Nazir et al (2010).

\section{Conclusion}

We have conducted a survey to inspect the effect of corporate dividend payout policy on stock price volatility. The main objective of this study was to examine the impact of dividend payout ratio on the stock price volatility in Pakistan Stock Exchange. A sample of 15 firms from PSX was taken and the study has covered a period of five years from 2011 to 2015. Stock Price volatility was the dependent variable in this study and dividend payout ratio was the main independent variable. For this purpose, 
some other independent variables were also included in the proposed model such as Earnings Volatility, Size of the firm, Leverage and Assets Growth. We have found a positive relationship between stock price volatility and dividend payout ratio. In addition, our results have shown that earnings volatility and Leverage had negative relationship with stock price volatility. Other independent variables including assets growth and size have maintained positive relationship with stock price volatility. Since both investors and management are afraid about the volatility of stock price, this research shed light on the path to discover what factors move the stock price and the main factors to be considered by investors before making investment decisions, and management in formulating dividend policies \& rules for their firm.

\section{References}

Azhagaiah, R., \& Priya, S. N. (2008). The impact of dividend policy on shareholders' wealth. International Research Journal of Finance and Economics, 20(3), 1450-2887.

Ansar, I., Butt, A. A., \& Shah, S. B. H. (2015). Impact of dividend policy on shareholder's wealth. International Review of Management and Business Research, 4(1), 89.

Baskin, J. (1989). Dividend policy and the volatility of common stocks. Journal of portfolio Management, 15(3), 19.

Black, F., \& Scholes, M. (1974). The effects of dividend yield and dividend policy on common stock prices and returns. Journal of financial economics, 1(1), 1-22.

Bawa, S. K., \& Kaur, P. (2013). Impact of Dividend Policy on Shareholder's Wealth: An Empirical Analysis of Indian Information Technology Sector. Asia-Pacific Finance and Accounting Review, 1(3), 17.

Friend, I., \& Puckett, M. (1964). Dividends and stock prices. The American Economic Review, 54(5), 656-682.

Gordon, M. J. (1963). Optimal investment and financing policy. The Journal of finance, 18(2), 264272.

Hussainey, K., Oscar Mgbame, C., \& Chijoke-Mgbame, A. M. (2011). Dividend policy and share price volatility: UK evidence. The Journal of risk finance, 12(1), 57-68.

Holder, M. E., Langrehr, F. W., \& Hexter, J. L. (1998). Dividend policy determinants: An investigation of the influences of stakeholder theory. Financial management, 27(3), 73-74.

Ilaboya, O. J., \& Aggreh, M. (2013). Dividend policy and share price volatility. Journal of Asian Development, 2(2), 109-122.

Iqbal, Z., Waseem, M. A., \& Asad, M. (2014). Impact of dividend policy on shareholders' wealth: A study of selected manufacturing industries of Pakistan. International Journal of Innovation and Applied Studies, 6(2), 210.

Khan, K. I. (2012). Effect of dividends on stock prices-A case of chemical and pharmaceutical industry of Pakistan. Management, 2(5), 141-148.

Modigliani, F., \& Miller, M. H. (1959). The cost of capital, corporation finance, and the theory of investment: Reply. The American Economic Review, 49(4), 655-669.

Miller, M. H., \& Modigliani, F. (1961). Dividend policy, growth, and the valuation of shares. the Journal of Business, 34(4), 411-433.

Miller, M. H., \& Rock, K. (1985). Dividend policy under asymmetric information. The Journal of finance, 40(4), 1031-1051

Masum, A. (2014). Dividend policy and its impact on stock price-A study on commercial banks listed in Dhaka stock exchange. Global Disclosure of Economics and Business, 3(1).

Nishat, M., \& Irfan, C. M. (2004). Dividend policy and stock price volatility in Pakistan. In Pide-19th annual general meeting and conference (pp. 13-15).

Nazir, M. S., Nawaz, M. M., Anwar, W., \& Ahmed, F. (2010). Determinants of stock price volatility in karachi stock exchange: The mediating role of corporate dividend policy. International Research Journal of Finance and Economics, 55(55), 100-107.

Pradhan, R. S. (2003). Effects of dividends on common stock prices: The Nepalese evidence. 
Profilet, K. A., \& Bacon, F. W. (2013).Dividend Policy and Stock Price Volatility in the US Equity Capital Market. ASBBS Proceedings, 20(1), 219.

Suliman, M., Ahmad, S., Anjum, M. J., \& Sadiq, M. (2013). Stock price volatility in relation to dividend policy; A case study of Karachi stock market. Middle-East Journal of Scientific Research, 13(4), 426-431.

Walter, J. E. (1956). Dividend policies and common stock prices. the Journal of Finance, 11(1), 2941.

Zakaria, Z., Muhammad, J., \& Zulkifli, A. H. (2012). The impact of dividend policy on the share price volatility: Malaysian construction and material companies. International Journal of Economics and Management Sciences, 2(5), 1-8.

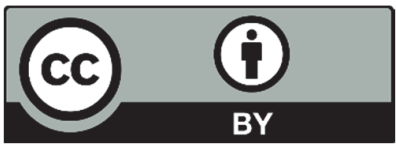

(C) 2019 by the authors; licensee Growing Science, Canada. This is an open access article distributed under the terms and conditions of the Creative Commons Attribution (CC-BY) license (http://creativecommons.org/licenses/by/4.0/). 